\title{
Returning to the Parental "Nest:" Exploring a Changing Canadian Life Course
}

\author{
Ellen M. Gee
}

Simon Fraser University

Burnaby, British Columbia, Canada

\author{
Barbara A. Mitchell
}

Simon Fraser University

Burnaby, British Columbia, Canada

\author{
Andrew V. Wister \\ Simon Fraser University \\ Burnaby, British Columbia, Canada
}

\section{Abstract}

Recently, there have been significant increases in co-residence among young adults and their parents: young adult children remain home longer and are more likely to return home after leaving. Prolonged intergenerational living, even if for sporadic intervals, represents a departure from the "rise of the primary individual" (Kobrin, 1976) witnessed in the second half of the twentieth century. These shifts in living arrangements suggest a complexity in the transition to adulthood that has tended to be neglected in life course research. In this paper, we focus on the phenomenon of young adult children returning to live at home, drawing upon a random sample of 218 returners and 202 home-leavers (non-returners) in the Greater Vancouver area in 1993-94. First, a descriptive account of returning home is provided on three dimensions: age at events (e.g., first home-leaving, first return); number of returns (single vs. multiple returns); and reasons for returning home. Age, sex, and marital status variations are also explored. Second, a proportional hazards analysis is performed on the rate of returning home, using several variables drawn from the life course perspective. The major predictors of returning home include: child's marital status, reason for leaving home, child's main activity, family type, and age at home-leaving. Theoretical implications of the results regarding families and life course transitions are discussed.

\section{Résumé}

Depuis peu, on note une augmentation significative de co-résidence parmi les jeunes adultes et leurs parents : les jeunes adultes restent au foyer familial plus longtemps et sont ensuite plus susceptibles d'y revenir. La cohabitation intergénérationnelle prolongée, même sporadique, constitue une démarcation par rapport à la montée de 
l'individualisme (rise of the primary individual) (Kobrin, 1976) observée au cours de la seconde moitié du vingtième siècle. Ce phénomène suggère une complexification du passage d l'âge adulte qui ne semble pas avoir retenue l'attention des spécialistes. Le présent article est consacré à l'étude d'un échantillon aléatoire de 218 jeunes adultes revenus au domicile familial et de 202 jeunes adultes qui l'ont quitté (sans y retourner) dans la région métropolitaine de Vancouver en 1993-94. Il propose d'abord un compte rendu descriptif en trois dimensions du retour au nid : âge lors des événements clés (premier départ, premier retour); nombre de retours (simple ou multiple); et motif du retour. L'âge, le sexe et l'état matrimonial sont également pris en compte. L'indice des retours au domicile familial fait ensuite l'objet d'une analyse proportionnelle des risques fondée sur plusieurs variables issues de la perspective du cours de la vie. Les principaux prédicteurs du retour incluent : l'état matrimonial de l'enfant, le motif du départ initial de la maison, l'activité principale de l'enfant, le type de famille, et l'âge au moment du départ initial. Les implications théoriques des résultats concernant les familles et les transitions sont examinées.

Key Words: living arrangements, young adults, returning home, life course

\section{Introduction}

Since the 1981 Canadian Census, a trend of increasing co-residence of young adults and parents has been observed. This phenomenon that has come to be known as the "cluttered nest" (Boyd and Pryor, 1989; Boyd and Norris, 1994). A similar demographic pattern has been noted in the United States (e.g., Glick and Lin, 1986; Grigsby and McGowan, 1986; DaVanzo and Goldscheider, 1990), and in western European countries, and has been attributed to both later ages at homeleaving and a greater likelihood of returning home (Aquilino, 1990; Ward and Spitze, 1992). The significance of the "cluttered nest" lies in its contradictory relationship with two broad changes in family life and life course transitions. First, it represents a departure from the more general trend toward non-family living arrangements among the unmarried population in western societies-the "rise of the primary individual" (Kobrin, 1976). For example, the proportionately larger numbers of divorced persons in these societies are likely to live alone, and widows, in particular, have experienced a significant rise in separate living arrangements (Wolf, 1990). In a similar vein, remarriage rates have decreased substantially in recent years (Ram, 1990). Second, the "cluttered nest" suggests an increasing complexity or "disorderliness" in the transition to adulthood (Goldscheider et al,, 1993), which is in keeping with research on other life course transitions.

Furthermore, a reversal in the transition to adulthood (often signified by the 
establishment of an independent household) may have many important ramifications. For example, returning home may affect parent-child relationships and patterns of support (Norris and Tindale, 1994; Shehan et al, 1984; Veevers and Mitchell, 1994), parental marital satisfaction (Clemens and Axelson, 1985; Mitchell and Gee, 1995), living arrangement satisfaction (Aquilino, 1991; Schnaiberg and Goldenberg, 1989; Ward and Spitze, 1992; Wister et al, 1996), as well as future life trajectories for the adult child. For these reasons, the increasing propensity for children to return home to live with their parental families (dubbed "boomerang kids") represents an important area of investigation.

In this paper, we explore one aspect of the trend of increasing co-residence of young adults and parents-returns to the parental home. Although co-residence in general has received attention in the literature, we argue that returning home represents a special type of co-residence separate from "delayed launching." In fact, researchers are beginning to specifically examine the determinants of returning home behaviour (e.g., DaVanzo and Goldscheider, 1990; Hartung and Sweeney, 1991; Mitchell and Gee, 1996; Goldscheider and DaVanzo, 1986; Goldscheider and Goldscheider, 1994). However, we are aware of no Canadian studies that have investigated the factors contributing to the likelihood of home returning.

\section{Theoretical Background}

The theoretical framework for this research draws from the life course perspective (e.g., Elder, 1985; Hagestad, 1990). Applying this perspective, returning home is viewed at the centre of a discord between normative expectations on the one hand, and reducing opportunity structures on the other hand, in the transition to adulthood. Parents and adult children maintain normative social time-tables about acceptable timing and sequence of significant life events, such as leaving and returning home (e.g., Foner, 1996, Veevers et al, 1996). However, these transition expectations may be redefined in the face of specific characteristics and circumstances of adult children and their parents. For example, returning home may be viewed as more acceptable if the adult child is looking for work or is continuing education, rather than employed. Also, an adult child who is married would probably have less need to return; however, he/she (and spouse and, perhaps, children) would place greater demands on the parental household than a single child.

A complementary aspect of life course theory is the proposition that earlier life decisions (such as a young "launch" out of the parental household) and the circumstances surrounding those transitions (i.e., the reason for leaving, in this case) may shape later life course behaviour (including a return home) (Elder, 
1985). For example, leaving home earlier in life would be expected to increase the probability of returning because of the difficulties encountered in maintaining an independent household at a younger age.

A preliminary descriptive analysis of returning home behaviour (age, number and reasons for returning home) will be guided by an examination of its prevalence, timing and duration, in light of traditional demographic variables such as age, sex and marital status. Also, we expect that the probability of returning home will differ in terms of individual and parental (family) variables, in line with the life course perspective's focus on multi-level determinants of transition behaviour. We first provide a descriptive overview of the returning home process in terms of ages at transitions, number of returns, and reasons for returns. Second, we perform a proportional hazards analysis of predictors of the risk of returning home.

\section{Data and Methods}

Sample and Design. This research is based on a sample of 420 families in which both a parent and a child were interviewed, separately, by telephone. Eligibility criteria for inclusion in the study are: residence in the Vancouver lower mainland; ability to communicate in English; age (19-35 for children and 35-60 for parents); and the interviewed child had to have left home for at least six months during the last ten years. Based upon the child's history of living arrangements, two sub-samples of children are formed for this research: home-leavers (the child has left home for at least six months and never returned within the last 10 years, $n=202$ ) and returners (the child has left home and returned at least once, for at least six months, with the last return occurring within the last 5 years, $n=218$ ). The returner sample includes both adult children who are currently residing in the parental home $(n=120)$, and those who recently experienced a return home but are no longer living in that arrangement $(\mathrm{n}=98)$.

The sampling pool consisted of household numbers listed in the Greater Vancouver Directory, with contacts made using Random Digit Dialing. In addition, approximately $10 \%$ of the sample was contacted through snowball sampling and through replies to advertisements placed in local newspapers. A total of 11,050 contacts were made. Of these, 318 were non-English-speaking; 9,760 were ineligible contacts due to lack of children, age (of parent and/or child), duration of return(s) home, duration of time away from home, or number of years since child had returned home; 552 were refusals; and 420 resulted in completed interviews (with both parent and child). However, it should be kept in mind that some ineligible contacts probably met the study inclusion criteria but were using the claim of ineligibility as an "easy way" to refuse. On the other hand, some refusals, especially cases with an immediate hang-up upon telephone 
contact, were undoubtedly not eligible anyway. We estimate that the response rate is about $50 \%$. Given the requirement that both a parent and child had to agree to be interviewed, this response rate is reasonable.

The child respondents include more females than males for both home-leaver and returner groups. Among the home-leavers, 128 (63\%) are women; among the returners, the comparable figure is $135(62 \%)$. The adult children sampled have an age range of 19 to 34 . The mean current age of the home-leavers is 25.4 years; for returners, 26.0 years. Since we lack baseline data on the distribution of the two types of children in the general population, we cannot assess the representativeness of our sub-samples in terms of age and sex. However, the two groups do not vary by age and sex composition, which facilitates comparisons between them.

Research Instrument. The research instrument is an interview consisting of differing versions. While all respondents were asked the same set of basic demographic and socio-economic questions, variants of the substantive part of the interview were needed for parents and children and for the differing living arrangement histories. The interview schedule is comprised of a combination of open and close-ended questions, taking approximately 30-45 minutes to complete. It sought information on a variety of issues; e.g., the timing and factors contributing to leaving and returning home, family relationships, perceptions of intergenerational exchanges, areas of conflict during co-residence, etc. Participants were assured that all information provided would be confidential, that they could withdraw at any time, that they did not have to answer questions if they chose not to, and that their names would not be linked with the research results.

Descriptive Analysis. We begin the descriptive analysis (means and percentages) with a comparison of the mean age of first (or only) home-leaving for returners and home-leavers by sex, current age, age at first home-leaving, marital status at home-leaving, and number of returns (for returners only). For returners, the mean age at first return and mean duration are presented separately by sex, current age (for first return only), age at first home-leaving, age at first return (for duration only), marital status at first return, and number of returns. Next, the primary reason for first (or only) home-leaving is compared for returners and homeleavers by sex, age at first (or only) home-leaving, and number of returns (for returners only). The final part of the descriptive section examines the primary reason for the first return home (returners only) by sex, age at first-home-leaving, age at first return, and number of returns.

Multivariate Analysis. In order to examine the effects of the independent variables in a multivariate model, a proportional hazards analysis was conducted 
(see description below). This provides an opportunity to examine the independent effects of several parental and child characteristics considered to affect patterns of returning home.

Dependent Variable. The dependent variable selected for the multivariate analysis is the survival time (exposure time) between first home-leaving and a first return home. Among home-leavers who have not returned home by the time of the survey, survival time is measured from the time of home-leaving to the survey date. These cases are censored at the time of the survey because of incomplete information about the event among some individuals who have not been fully exposed to the risk of returning home, which is attributable to the cross-sectional design. Proportional hazards modelling is one type of event history analysis that has been designed to deal specifically with this type of data problem (Yamaguchi, 1991). The range in duration is 0.5 to 14 years; the mean is 3.36 years with a standard deviation of 2.89 years.

Independent Variables. The independent variables include three parental characteristics and seven child characteristics. An advantage of this data set is that several of the independent variables (e.g., reason for home-leaving, family type, marital status of child, and main activity of child) are time-nested, that is, they are measured at the time of the home-leaving or the first return, rather than at the time of the survey only. Some of the other independent variables (e.g., parental education and income, and the religiosity of children) are considered to be relatively stable over time.

The purpose of this analysis is to examine a number of independent variables expected to affect the rate at which young adults return home bocause of their salience to life course transitions. The circumstances surrounding home-leaving and returning home are viewed as important factors affecting the desirability and acceptability of returns to the nest. In addition, certain characteristics of parents and children are expected to affect opportunity structures. Three parental variables are included in the analysis: family type, education and income. Family type is measured at the time of the last return for returners and at the time of the survey for home-leavers. It is expected that the probability of a home return is greater among those who come from an intact family than a step family, since step-children are associated with more familial conflict than biological children (Goldscheider and DaVanzo, 1986; Mitchell et al, 1989; White and Booth, 1985). The data are collapsed into single, step-family and biological family types.

Education and income are used as measures of socio-economic status (SES). It is anticipated that higher parental SES will result in a lower likelihood of returning home, given that higher SES parents tend to have greater achievement expectations of their children coupled with the fact that they tend to have more 
Returning to the Parental "Nest:" Exploring a Changing Canadian Life

financial resources with which to support an adult child's independent living arrangement (Aquilino, 1991; Avery et al, 1992; Schnaiberg and Goldenberg, 1989). Education and income are measured at the time of the survey and are trichotomized as follows: parent respondent education (some high school or less, high school grad/some post secondary, post secondary degree) and parental household income $(\$ 39,999, \$ 40,000-\$ 79,999, \$ 80,000+)$.

Seven child characteristics are included in the analysis: sex, religiosity, ethnic origin, marital status, age at home-leaving, reason for leaving home, and main activity. The first four variables are socio-demographic characteristics considered to affect returning home; the remaining three tap into the circumstances surrounding home-leaving and returning. Marital status and main activity are measured at the time of the last return for returners and at the time of the survey for home-leavers.

Regarding sex of "boomerang kids," sons are expected to have higher rates of returning than daughters (Avery et al, 1992; DaVanzo and Goldscheider, 1990; Glick and Lin, 1986; Goldscheider and Goldscheider, 1994). Sons tend to marry later, and daughters may be deterred from returning because they anticipate that their parents will closely supervise their social lives and expect more help with domestic tasks (e.g., see Boyd and Pryor, 1989). Adult children who are more religious and those who come from a non-western ethnic origin may be more likely to return home, since cultural characteristics have been shown to affect preferences for extended periods of co-residence or because they reflect economic need (e.g., see Aquilino, 1990; Boyd and Pryor, 1989). Religiosity is dichotomized as some or none; ethnic origin is collapsed into Commonwealth, other European, and "other" countries of origin.

It is also expected that the marital status of the adult child will affect the propensity of returning home (Goldscheider and Goldscheider, 1994). Those who are unmarried are expected to return home more than married or ever-married children because these returns do not entail the additional burden of more than one returnee household member (i.e., a spouse and/or children). In short, there may be limits to the use of the parental home as a "safety net" or as a "home base" during times of need. Adult child's marital status is measured using three categories (never-married, ever married, married/common-law).

Life course theory suggests that the timing of and reasons for the initial departure are of particular importance to life trajectories. Adult children who leave home earlier in life are expected to be more likely to return home (Goldscheider and DaVanzo, 1986). An early departure from home may signify an "incomplete" transition and can affect one's ability to maintain a separate dwelling. The reason for leaving-home may also affect returning patterns. For example, those who left 
home due to conflict are expected to be more likely to return home, possibly because this decision was not carefully planned and did not follow "definitions of appropriate behaviour" (DaVanzo and Goldscheider, 1990:242). The categories used to measure reason for leaving home include: form a relationship, work, conflict, school, independence, "other"). Furthermore, young adults' main activity after leaving home may affect the propensity for returning. Adult children who are looking for work or attending school are anticipated to return at higher rates than those who are employed. Parents may be more accepting of "role reversals" at this stage of the life course if their children do not have the means to live independently (Hartung and Sweeney, 1991). The following main activity types are used: looking for work, student, employed, "other." Main activity should be treated with caution because our measure does not capture multiple changes in activity that may have occurred since home-leaving. Also, it should be noted that primary reason for returning home could not be included in the analysis because of the inclusion of home-leavers (who had not returned by the time of the survey) in the data.

The coding and frequency distributions of the independent variables used in the survival analysis are presented in Appendix A. Investigation of the correlation matrix of the independent variables (not shown in tabular form) does not reveal problems of multicollinearity for the multivariate analysis.

Survival Analysis. Proportional hazards modelling is an event history technique that is useful for analysing the rate at which young adults return home after a home-leaving event (Teachman and Hayward, 1993). A parametric hazard model is used to estimate the hazard rate of returning home (the duration between homeleaving and returning) for a set of parental and adult child variables among our sample of adult children aged 19 to 34. The parametric model for the response variable, duration (survival) of home-leaving, consists of a linear effect made up of the covariates combined with the random disturbance term. The model assumed for the response variable $Y$ is:

$$
Y=\exp (X B)+\sim e
$$

where $\mathrm{Y}$ is the vector of the response values (often the $\log$ of the failure times), exp. is the exponential of the regression parameter, $\mathrm{X}$ is a matrix of covariate values, $B$ is a vector of unknown parameters to be estimated, $\sim$ is an unknown scale parameter, and $\mathrm{e}$ is a vector of errors from a selected distribution. A Weibull distribution (exponential distribution with a scale parameter instead of restricting the scale to 1) was assumed for the failure time. We selected a Weibull distribution for the baseline hazard function of returning home because we assume a distribution that is similar to that observed for home-leaving (see Mitchell, 1994). 


\section{Results}

Descriptive Data. In the first part of this analysis, we focus on children who have returned home (for a minimum period of six months within the last five years), making some comparisons with home-leavers, when meaningful. In our sample, most returning children do so only once (72\%), although $19 \%$ return home $2-3$ times, and $9 \%$ return home $4-5$ times.

Table 1. Mean Age at First/Only Home-Leaving for Returners and HomeLeavers, Showing Sex, Current Age, Marital Status at HomeLeaving, and Number of Returns Home

\begin{tabular}{|c|c|c|}
\hline & $\begin{array}{c}\text { Returned } \\
\text { Mean Age at (First) } \\
\text { Home-Leaving }\end{array}$ & $\begin{array}{l}\text { Home-Leavers } \\
\text { Mean Age at (Only) } \\
\text { Home Leaving }\end{array}$ \\
\hline Total & $19.1 \quad(218)$ & $20.5 \quad(202)$ \\
\hline $\begin{array}{l}\text { Sex } \\
\text { Males } \\
\text { Females }\end{array}$ & $\begin{array}{ll}19.1 & (81) \\
19.1 & (135)\end{array}$ & $\begin{array}{ll}20.8 & (74) \\
20.4 & (128)\end{array}$ \\
\hline $\begin{array}{l}\text { Current Age } \\
18-24 \\
25-29 \\
30-34\end{array}$ & $\begin{array}{ll}18.6 & (88) \\
19.5 & (89) \\
19.5 & (38)\end{array}$ & $\begin{array}{ll}19.4 & (93) \\
21.3 & (90) \\
22.6 & (19)\end{array}$ \\
\hline $\begin{array}{l}\text { Marital Status at } \\
\text { Home-Leaving } \\
\text { Married/Common- } \\
\text { Law } \\
\text { Never-Married } \\
\text { Ever-Married }\end{array}$ & $\begin{array}{l}19.8(13) \\
19.1 \quad(205) \\
-\end{array}$ & $\begin{array}{ll}21.4 & (40) \\
20.3 \quad(162) \\
\end{array}$ \\
\hline $\begin{array}{l}\text { Number of Returns } \\
\text { Home } \\
1 \\
2-3 \\
4-5\end{array}$ & $\begin{array}{ll}19.3 & (157) \\
18.8 & (41) \\
18.0 & (20)\end{array}$ & $\begin{array}{l}- \\
-\end{array}$ \\
\hline
\end{tabular}

Since home-leaving is the logical first step in the process (i.e., leaving precedes returning), we begin with an examination of data on the mean age at first homeleaving (see Table 1). Comparing returners and home-leavers, we observe that children who eventually return home tend to leave home almost one and one-half 
years younger than children who remain away. The only other noteworthy difference between home-leavers and returners is that the latter are more likely to be single (never-married) at the time of home-leaving; however, the majority of both groups are never-married at home-leaving.

Table 2. Mean Age at First Return Home, Showing Sex, Current Age, Age at First Home-Leaving, Marital Status at First Return and Number of Returns Home

Mean Age at First Return

Total

$21.2(218)$

Sex

Males

$21.2(83)$

Females

Current Age

$18-24$

$19.6(88)$

$25-29$

$22.0 \quad(89)$

$30-34$

22.4 (38)

Age at First Home-Leaving

$<19$

$19.3(90)$

$19+$

$22.6(128)$

Marital Status at First Return

Home

Married/Common-Law

Never-Married

$23.0 \quad(18)$

Ever-Married

$20.9(190)$

23.8 (10)

Number of Returns Home

1

$2-3$

21.6 (156)

$4-5$

20.8 (40)

19.4 (19)

Focussing on returner children, the mean age at first home-leaving is 19.1 years, with no sex difference. The mean age is younger for persons currently aged 18-24 (18.6) than for those aged 25 and over (19.5). Almost all returners are not married at the time of first home departure, rendering useless distributional data on age at home-leaving by marital status at time of home-leaving. Table 1 also indicates a relationship between age at first home-leaving and number of returns 
home, i.e., the younger the age at home-leaving, the greater the likelihood of multiple returns. Overall, the data in Table 1 suggest that home-leaving age is unrelated to gender and marital status, but is associated with returning home behaviour in two ways. First, the younger the age at first home-leaving, the greater the likelihood of returning home; and second, the younger the age at first home-leaving, the greater the probability of returning home more than once.

The mean age at first return home is $\mathbf{2 1 . 2}$ years, and does not differ by sex. See Table 2. Younger age at first return is associated with younger current age, younger age at first home-leaving, never-married marital status, and multiple returns home. The first three relationships are expected, given age-related selectivities associated with life course transitions. However, the relationship between age at first retum and number of returns home is noteworthy, suggesting that young age at home-leaving and home-returning is a good indicator of an "incomplete" transition to adulthood. This finding also suggests that a relatively small group of persons-who (leave home and) return home at young agesaccounts for a disproportionate amount of returns to the parental home.

Overall, the mean duration of time (in years) between first homeleaving and first return, as portrayed in Table 3 , is approximately 2 years. Variations occur along the dimensions of age at first return, marital status at first return, and number of returns home (and again, not gender). As might be expected, adult children who return home at younger ages ( $<21$ years) have a much shorter period of time "on their own" (mean=1.1 years) than persons who return home at older ages (mean=3.0 years). However, a similar relationship does not exist between age at first home-leaving and duration of time between first home-leaving and first return. This suggests that something other than merely time accounts for the relationship between age at first return and duration between home-leaving and returning. To some degree, another factor is differences in marital status, but the numbers of persons who are not never-married is too small for this to be a major determinant. It is possible that persons who first return home at older ages $(21+)$ take longer to do it, given normative prescriptions about independent living (Veevers et al,, 1996), and perhaps have different reasons for returning. It can also be noted in Table 3 that the mean duration time between first home-leaving and first return is shorter for multiple returners, particularly those with 4-5 returns home. 
Ellen M. Gee, Barbara A. Mitchell and Andrew V. Wister

Table 3. Mean Duration of Time (in years) Between First Home-Leaving and First Return, by Sex, Age at First Home-Leaving, Age at First

Return, Marital Status at First Return, and Number of Returns

Home

Mean Duration (years)

Total

$2.1(218)$

Sex

Males

Females

$2.0(83)$

2.1 (135)

Age at First Home - Leaving

$<19$

$2.2(90)$

$19+$

1.9 (128)

Age at First Return

$<21$

$1.1(107)$

$21+$

3.0 (111)

Marital Status at First Return

Married/Common - Law

3.5 (18)

Never - Married

$1.8(190)$

Ever-Married

4.8 (10)

Number of Returns Home

1

$2-3$

2.2 (156)

$4-5$

$2.0 \quad(40)$

1.5 (19)

In an attempt to shed light on the above findings, we now turn to data on perceived reasons for home-leaving and home-returning. Table 4 presents data on the primary or most important reason, provided by the child respondents, for (first or only) home-leaving. The somewhat nebulous "wanted independence" is the reason most frequently provided as most important by both home-leavers and returners, although more so by home-leavers $(42.6 \%)$ than by returner children (30.9\%). A major difference between the two groups relates to relationship formation as the primary reason for home-leaving- $27.2 \%$ among home-leavers and $11.5 \%$ among returners. In contrast, returners are more likely to initially leave home for work and because of conflict at home. 
Table 4. Percentage Distribution of Primary Reason for First Home-Leaving, for Returners and Homeleavers, by Sex, Age at First Home-Leaving and Number of Returns

\begin{tabular}{|c|c|c|c|c|c|c|c|c|}
\hline \multirow[b]{4}{*}{$\begin{array}{l}\text { Primary Reason: } \\
\text { To Form } \\
\text { Relationship }\end{array}$} & \multirow[t]{2}{*}{ Total } & \multicolumn{2}{|c|}{ Sex } & \multicolumn{2}{|c|}{$\begin{array}{l}\text { Age at First } \\
\text { Home-Leaving }\end{array}$} & \multicolumn{3}{|c|}{ Number of Returns } \\
\hline & & M & F & $<19$ & $19+$ & 1 & $2-3$ & $4-5$ \\
\hline & \multicolumn{8}{|c|}{ Returners } \\
\hline & 11.5 & 8.5 & 13.3 & 9.8 & 14.0 & 12.8 & 4.8 & 15.0 \\
\hline To Go To Work & 18.4 & 19.5 & 17.8 & 9.1 & 19.0 & 17.9 & 19.5 & 20.0 \\
\hline To Go To School & 15.7 & 11.0 & 18.5 & 16.8 & 11.0 & 16.7 & 14.6 & 10.0 \\
\hline $\begin{array}{l}\text { Wanted } \\
\text { Independence }\end{array}$ & 30.9 & 36.6 & 27.4 & 36.4 & 36.0 & 32.1 & 29.3 & 25.0 \\
\hline Conflict at Home & 12.9 & 17.1 & 10.1 & 22.4 & 8.0 & 11.5 & 17.1 & 15.0 \\
\hline Other & 10.6 & 7.3 & 12.9 & 5.6 & 12.0 & 9.0 & 14.7 & 15.0 \\
\hline $\begin{array}{l}\text { To Form } \\
\text { Relationship }\end{array}$ & 27.2 & 20.3 & 31.3 & $\begin{array}{c}\text { Home } \\
15.1\end{array}$ & $\begin{array}{l}\text { Leavers } \\
31.6\end{array}$ & - & - & - \\
\hline To Go To Work & 4.5 & 8.1 & 2.3 & 1.9 & 5.4 & - & - & - \\
\hline To Go To School & 11.4 & 16.2 & 8.6 & 17.0 & 9.4 & - & $\cdot$ & - \\
\hline $\begin{array}{l}\text { Wanted } \\
\text { Independence }\end{array}$ & 42.6 & 40.5 & 43.0 & 35.8 & 44.3 & - & - & - \\
\hline Conflict at Home & 8.9 & 5.4 & 10.9 & 22.6 & 4.0 & - & - & - \\
\hline Other & 5.4 & 9.5 & 3.9 & 7.6 & 5.3 & . & - & - \\
\hline
\end{tabular}

Among returners, some gender differences emerge when examining the primary reason for first home-leaving. Young women are more likely than men to leave to form a relationship and to go to school, and less likely to leave for independence and because of home conflict. Only one of these gender differences, relationship formation, is repeated within the home-leaver group. In terms of age at first home-leaving, returners who left home young are more likely to cite conflict at home and less likely to provide relationship formation and work as primary reasons for first home-leaving, in comparison with returners who initially left home at older ages. Similar differences exist among the home-leavers. 


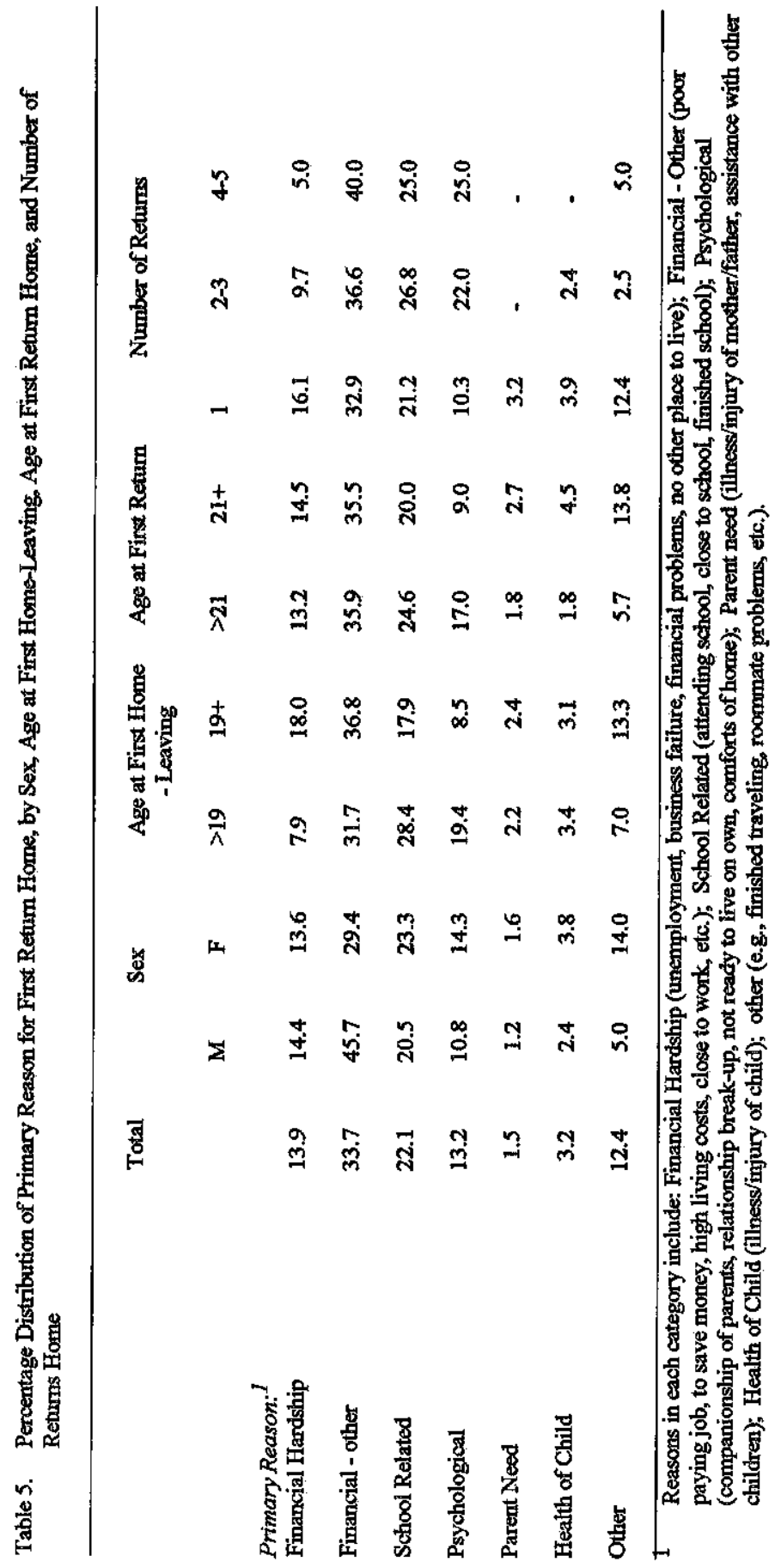


Data on the most important reason for the last return (which, it will be recalled, is the only return for $72 \%$ of the sample) are provided in Table 5 . The reasons given are clearly related to child's, rather than parental, needs. Overall, about one-half of the reasons are financial, which fits in with everyday notions that children are returning home because of the worsening economic climate and high rates of unemployment. However, it does not appear that economic hardship per se is a major reason; rather, the Financial-Other reasons (particularly "to save money") are more important which is in keeping with that of DaVanzo and Goldscheider (1990) and Hartung and Sweeney (1991). Another important reason, with financial aspects itself, is school attendance. Nearly $30 \%$ of the returners who had left home before the age of 19 cite schooling as the primary reason for their return home; thus, normative prescriptions about completing school before homeleaving appear to be breaking down. Psychological reasons constitute a nonnegligible percentage of responses such as wanting the comforts of home and the companionship of parents and not feeling ready to be on one's own. Psychological reasons are more often reported by persons who left home young, return home young, and return home more than once. Therefore, it appears that, at least for some children, the option to attempt an early transition to adulthood exists, an option which contains a safety valve - the parental home.

Proportional Hazards Analysis. Table 6 provides the parameter estimates, standard errors, chi-square statistics, level of statistical significance, and the hazard rate for the proportional hazards model. Teachman and Hayward (1993:342) state that the baseline hazard function:

"refers to the instantaneous rate of experiencing the event when all of the covariates take the value of $0 \ldots$ and while constant across individuals, can vary across time. For a one unit increase in a given covariate, $\mathrm{X}$, the multiplicative change in the baseline hazard rate is given by exp. (B). A simple transformation of the parameter estimate for a given covariate, 100 (exp. (B) - 1), yields the percentage change in the hazard rate for a one-unit increase in the predictor variable."

It should be noted that the parameter estimates and hazard rates should be interpreted carefully. A Weibull hazard function models the natural logarithm of the survival times in a state of home-leaving. Positive estimates indicate longer duration times or a lower hazard rate of returning home; negative estimates indicate shorter duration times or a higher hazard rate of returning home. A chisquare statistic is computed for each parameter estimate to evaluate the level of statistical significance (Parker, 1977). The parameter estimate, chi-square, and $p$ level are provided for each interval-level variable and for each category of nominal level variables (coded as one) except for the last category, which is 
treated as the comparison group (coded as zero) to create a series of dummy variables.

Table 6: Proportional Hazards Model for Returning Home

\begin{tabular}{|c|c|c|c|c|}
\hline Parental Variables & $\begin{array}{c}\text { Parameter } \\
\text { Estimate }\end{array}$ & $\begin{array}{l}\text { Standard } \\
\text { Error }\end{array}$ & Chi-Square & $\begin{array}{c}\text { Hazard } \\
\text { Rate }\end{array}$ \\
\hline $\begin{array}{l}\text { Family Type } \\
\text { single } \\
\text { step } \\
\text { biological (ref) }\end{array}$ & $\begin{array}{l}0.31 \\
0.47\end{array}$ & $\begin{array}{l}0.18 \\
0.22\end{array}$ & $\begin{array}{c}6.21^{*} \\
3.04 \\
4.63^{*}\end{array}$ & $\overline{60 \%}$ \\
\hline $\begin{array}{l}\text { Respondent Education } \\
\text { some h.s. or less } \\
\text { some h.s. grad/some post } \\
\text { post-sec. degree (ref) }\end{array}$ & $\begin{array}{l}-0.02 \\
-0.15\end{array}$ & $\begin{array}{l}0.23 \\
0.13\end{array}$ & $\begin{array}{l}1.34 \\
0.01 \\
1.24\end{array}$ & - \\
\hline $\begin{array}{l}\text { Household Income } \\
\qquad=\$ 39,999 \\
\$ 40,000-\$ 79,999 \\
\$ 80,000+\text { (ref.) }\end{array}$ & $\begin{array}{r}-0.28 \\
0.07\end{array}$ & $\begin{array}{l}0.20 \\
0.15\end{array}$ & $\begin{array}{l}4.11 \\
1.91 \\
0.22\end{array}$ & - \\
\hline $\begin{array}{l}\text { Child Variables } \\
\text { Gender } \\
\text { female } \\
\text { male (ref.) }\end{array}$ & -0.02 & 0.13 & 0.03 & -- \\
\hline $\begin{array}{l}\text { Religiosity } \\
\text { rarely (ref.) } \\
\text { sometimes } \\
\text { regularly }\end{array}$ & $\begin{array}{r}0.03 \\
-0.10\end{array}$ & $\begin{array}{l}0.16 \\
0.23\end{array}$ & $\begin{array}{l}0.44 \\
0.03 \\
0.21\end{array}$ & - \\
\hline $\begin{array}{l}\text { Ethnic Origin } \\
\text { other European } \\
\text { other } \\
\text { Commonwealth (ref.) }\end{array}$ & $\begin{array}{r}0.11 \\
-0.11\end{array}$ & $\begin{array}{l}0.23 \\
0.15\end{array}$ & $\begin{array}{l}0.92 \\
0.23 \\
0.53\end{array}$ & - \\
\hline Age at Home-Leaving & 0.08 & 0.03 & $7.47^{* *}$ & $9 \%$ \\
\hline $\begin{array}{l}\text { Marital Status } \\
\text { never married } \\
\text { ever married } \\
\text { married/c.l. (ref.) }\end{array}$ & $\begin{array}{l}-2.01 \\
-0.83\end{array}$ & $\begin{array}{l}0.25 \\
0.37\end{array}$ & $\begin{array}{c}69.76^{* * * *} \\
65.39^{* * *} \\
4.89^{*}\end{array}$ & $\begin{array}{l}-87 \% \\
-56 \%\end{array}$ \\
\hline
\end{tabular}


Table 6 cont'd.

\begin{tabular}{|c|c|c|c|c|}
\hline Parental Variables & $\begin{array}{l}\text { Parameter } \\
\text { Estimate }\end{array}$ & $\begin{array}{l}\text { Standard } \\
\text { Error }\end{array}$ & Chi-Square & $\begin{array}{c}\text { Hazard } \\
\text { Rate }\end{array}$ \\
\hline Reason Leaving & & & $35.20^{* * *}$ & \\
\hline form relationship & -0.40 & 0.23 & 3.09 & - \\
\hline work & -0.69 & 0.19 & $13.72 * * *$ & $.50 \%$ \\
\hline conflict & -0.32 & 0.21 & 2.21 & - \\
\hline school & 0.33 & 0.21 & 2.53 & - \\
\hline $\begin{array}{l}\text { other } \\
\text { independence (ref.) }\end{array}$ & -0.81 & 0.22 & $13.87^{* * *}$ & $-55 \%$ \\
\hline Main Activity & & & $33.30^{* * *}$ & \\
\hline looking for work & -0.85 & 0.22 & $14.51^{* * *}$ & $.57 \%$ \\
\hline student & -0.20 & 0.17 & 1.35 & - \\
\hline $\begin{array}{l}\text { other } \\
\text { employed (ref.) }\end{array}$ & -0.82 & 0.17 & $24.57^{* k *}$ & $-56 \%$ \\
\hline Intercept & 2.07 & 0.71 & $8.57^{* *}$ & \\
\hline Log-likelihood of Weibull $=$ & -433.65 & & & \\
\hline
\end{tabular}

scale $=0.88$

${ }^{*} p<.05 \quad{ }^{* *} p<.01 \quad * * * p<.001$

h.s. $=$ high school, post $=$ post secondary, o.1. $=$ common law

Only one parental variable - parental family type - is statistically significant. Adult children who have a step-parent at the time of the first return (or at the time of the survey for home-leavers) have a hazard rate of returning home that is $60 \%$ lower than those with biological parents. The single/biological parent contrast does not arise as statistically significant. Also, the parent respondent's education and the parental household income have insignificant effects on the probability of returning home.

Four of the seven adult child characteristics are significant predictors of returning home: age at home-leaving, marital status of child, reason for home-leaving, and main activity. These four variables are discussed in order of importance. As expected, marital status of adult children has a significant effect on the probability of returning home. Never-married adult children have a hazard rate of returning home that is $87 \%$ higher than those who are married. Also, the hazard rate for ever-married adult children is $56 \%$ higher. Thus, single and ever-married are considerable more likely to return to the parental "nest" than married adult children. Main activity also is found to be a strong predictor of returning home. 
Adult children who are looking for work, and those in the "other" category, display hazard rates of returning that are $57 \%$ and $56 \%$ higher, respectively, than adult children who are employed. The studentemployed dichotomy is not statistically significant.

Reason for leaving home is also very important in determining patterns of returning home. Adult children who leave home for employment, and those who leave home for "other" reasons (e.g., to travel) have hazard rates that are $50 \%$ and $\mathbf{5 5 \%}$ higher than those who leave home to achieve independence. The other leaving home reasons (to form a relationship, conflict and school) are insignificant factors. Finally, the age at home-leaving is shown to slightly decrease the hazard rate of returning home (hazard rate $=9 \%$ ). Adult children who leave later are less likely to return home. And conversely, early leavers are more likely to return home. The sex, level of religiosity and ethnic origin of the adult child do not surface as important predictors of returning home.

\section{Discussion}

Taken together, the data here inform us about returning home in a number of ways. While it has been recognized that the "cluttered nest" contains two dimensions (later age at home-leaving and returns to the parental home), it has not been emphasized that these two aspects represent different behoviours and different persons. The returners, our focus here, are likely to leave home at early ages, with multiple returners leaving home at the youngest ages. Thus, they exhibit a very different pattern of behaviour than delayed home-leavers, with whom they are often aggregated as constituent of the "cluttered nest."

That both earlier and later home-leaving contribute to the "cluttered nest" phenomenon illustrates the layers of tension between economic factors and normative expectations (i.e., social time-tables) in the transition to adulthood. For example, returners tend not to return home out of dire economic necessity, but rather in an attempt to "get ahead" financially; returning home is a "resource" that may be used, despite normative expectations of independent living. This is an important point, because it serves to counter overly-simplistic accounts of the role of a declining economy in affecting the transition to adulthood. All too often, increased co-residence of young adult children and parent(s) is viewed as a direct function of rising unemployment rates and reduced economic opportunities for the young. A recent Canadian work (Côté and Allahar, 1994) refers to today's young people as a "generation on hold," negatively characterized by a prolonged dependency on parents (including longer co-residence) as the direct result of diminishing economic prospects. However, our data suggest a more complicated picture. Not only are children more likely to return home in order to get ahead 
financially than because they are "flat broke," but this is the case regardless of parental socio-economic status (as measured by parental education and income).

Another aspect of the tension between economic factors and normative expectations is that changing normative prescriptions about school completion and home-leaving sequencing (a dimension of social time-tables), in conjunction with declining economic (job) opportunities, result in children leaving home before finishing school, but may create circumstances that increase their likelihood of returning home. For example, youth leaving home to gain employment are considerably more likely to return than if they leave home to achieve independence.

This illustrates that earlier decisions can shape later life-course behaviour. In the same vein, the timing of home-leaving sets up a "chain reaction;" it is not only that earlier timing affects later timing (which is a well-known tenet of the life course perspective), but also that earlier timing contributes to the actual occurrence (or non-occurrence) of a life course event, in this case returning home. The life course trajectory, then, is conditioned (not determined, of course) by time-tabling at younger ages.

Our data also suggest that, while we may have created a normative "looseness" about home-leaving (i.e., a diminution in social time-tables, at least behaviourally), our society has not produced the social-psychological conditions to support young people "on their own." This can be seen in Table 5, which indicates that persons who leave home at young ages and persons with multiple returns are more likely to give psychological reasons for their first return home. Such data may exemplify a youthful version of "age and structural lag" (Riley et al, 1994).

The data here bear on the question of the relative importance of children's versus parental variables in home-returning behaviour in two ways: 1) the data on reasons for returning (Table 5) show that children's needs predominate by a substantial margin; and 2) the proportional hazards analysis (Table 6) reveals that child characteristics are more important than parental variables in determining the likelihood of returning home. If children want or need to return home, there is a place for them, for the most part, regardless of family characteristics. That family/household extension is generally possible, even if for sporadic time periods only, reveals a flexibility in living arrangements and a durability in family relationships that make the often strident claims about family decline at the end of the twentieth century (e.g., Gairdner, 1992) questionable. However, it is the case that children whose parent(s) is remarried are much less likely to return to the parental home. Interestingly, children whose parents are single are not similarly constrained from returning home, illustrating in another way that familial 
economic circumstance is not a decisive factor in returning home. However, the data regarding children in step families suggest that the life course transitions of other family members may play a role in life course trajectories.

Overall, the results of the proportional hazards analysis indicate that returning home is conditioned by factors related to home-leaving (e.g., age at home-leaving, reason for leaving, main activity after leaving home), giving clear support to the life course theory's emphasis on the inter-relatedness of life course transitions. Variables that the child has no control over, such as parental SES, gender, and ethnic origin do not surface as significant predictors of returning home. These findings suggest an individuated life course, but one that is influenced by choices/decisions made at young ages.

\section{Endnotes}

1. These eligibility criteria reduce the generalizability of our findings. Specifically, our results cannot be extended to non-English-speaking families, dyads in which there is a large age gap between parent and child, and situations where children letave home for very short periods.

2. The two types of returners do not differ in age and sex composition, and the average length of time since last living at home is only $3 / 5$ years for those currently not living with their paremts.

3. It has been reposted that young men are more likely to return home than young women (DaVanzo and Goldscheider, 1990). If that is the case in Canada as well, our sample of adult children over-represents females.

4. It should be kept in mind that the two groups are almost identical in current age and sex distribution

5. We lack the data to examine the duration of time between retums.

6. The reasons ane obtained from a structured question, with the option of a self-selected response.

7. Includes both marriage and common-law arrangements. The majority of cases are common-law arrangements.

8. It will be recalled that marital status and main activity are measured at the time of the first return for returners, and at the time of the survey for home-leavers. Age and reason for home-leaving are measured at the time of home-leaving for all respondents.

9. The overall lack of gender differences in this study is worthy of note. Other research indicates that women leave home at earlier ages, and young men are more likely to retum home (Da Vanzo and Goldscheider, 1990; Mitchell, 1994). We cannot ascertain whether our data reflect a convergence between males and females in recent years, or if our sample is simply anomalous. 


\section{References}

Avery, R., F. Goldscheider, and A. Speare, Jr. 1992. Feathered nes/gilded cage: Parental income and leaving home in the transition to adulthood. Demography 29:375-388.

Aquilino, W.S. 1990. The likelihood of parent-adult child conesidence: Effects of family structure and parental characteristics. Journal of Marriage and the Family 52:405-419.

Aquilino, W.S. 1991. Family structure and home-leaving: A further specification of the relationship. Journal of Marriage and the Family 53:999-1010.

Boyd, M. and E.T. Pryor. 1989. The cluttered nest: The living arrangements of young Canadian adults. Canadian Journal of Sociology 14:461-477.

Boyd, M. and D. Norris. 1994. The cluttered nest revisited: Young Canadian acults at home in the 1990s. Paper presented at the annual meeting of the Canadian Population Society, Calgary, Alberta, June.

Clemens, A.W. and LJ. Axelson. 1985. The not-so-mpty nest: The return of the fledgling adult. Family Relations 34:259-264.

Cóté, J.E. and A.L. Allahar. 1994. Generation on hold: Coming of Age in the Late Twentieth Century. Toronto: Stoddart.

DaVanzo, J. and F.K. Goldscheider. 1990. Coming home again: Returns to the parental home of young adults. Population Studies 44:241-255.

Elder, G.H. Jr. 1985. Lffe Course Dynamics, Trajectories and Transitions, 1968-1980. Ithaca, NY: Comell University Press.

Foner, A 1996. Age norms and the structure of consciousness: Some final comments. Gerontologist $36: 221-223$.

Gairdner, W.D. 1992. The War Against the Family: Toronto: Stoddart.

Glick, P.C. and S. Lin 1986. More young adults are living with their parents: Who are they? Journal of Marriage and the Family 48:107-112.

Goldscheider, F.K. and J. DaVanzo. 1986. Semiautonomy and leaving home in early adulthood. Soctal Forces 65:187-201.

Goldscheider, F.K. and C. Goldscheider. 1994. Leaving and returning home in 20th century America Population Bulletin 48.Washington, DC: Population Reference Bureau, Inc.

Goldscheider, F., A. Thomton, and L. Young-DeMarco. 1993. A portrait of the nest-leaving process in early adulthood. Demography 30:683-699.

Grigsby, J. and J.B. MoGowan. 1986. Still in the nest: Adult children living with their parents. Sociology and Social Research 70:146-148.

Hagestad, G.O. 1990. Social perspectives on the life course. In R.H. Binstock and L.K. Goorge (eds.), Handbook of Aging and the Social Sciences (3rd ed.). New York: Academic Press. 
Hartung, B. and K. Sweeney. 1991. Why adult children return home, Social Science Journal 28: 467-480.

Kobrin, F. 1976. The fall in family size and the rise of the primary individual in the United States. Demography 13:127-138.

Mitchell, B.A. 1994. Family structure and leaving the nest: A social resource perspective. Sociological Perspectives 37:651-671.

Mitchell, B.,A and E.M. Gee. 1995. "Boomerang kids" and mid-life parental marital satisfaction Paper presented at the amnual meetings of the Canadian Association on Gerontology, Vancouver, October.

Mitchell, B.A. and E.M. Gee. 1996. Young acults returning home: Implications for social policy. In B. Galaway and J. Hudson (eds), Youth in Transition to Adulthood: Research and Policy Implications, pp. 61-71. Tononto: Thompson Educational Publishing.

Mitchell, B..A, A.V. Wister, and T.K. Burch 1989. The family environment and leaving the parental home. Journal of Marriage and the Famtly 51:605-613.

Norris; J.E. and J.A. Tindale. 1994. Among Generations: The Cycle of Adult Relationshtps. New York: W.H. Freeman and Company.

Parker, C., (ed). 1977. SASSTAT Guide for Personal Computers, Version 6, Cary, NC: SAS Institute Inc.

Ram, B. 1990. New trends in the family: Demographic facts and features. Ottawa: Statistics Canada Catalogue No. 91-535E.

Riley, M.W., R.L Kahn and A. Foner (eds.). 1994. Age and Structural Lag: Society's Fatlure to Provide Meaningful Opportunities in Work, Family, and Leisure. New York: Jchn Wiley \& Sons.

Schnaiberg, A. and S. Goldenberg. 1989. From empty nest to crowded nest: The dynamics of incompletelylaunched young adults. Social Problems 36:251-269.

Shehan, C.L, D.H. Berardo, and F.M. Berardo. 1984. The empty nest is filling again; Implications for parent-child relationships. Parenting Studies 1:67-73.

Teachman, J.D. and M.D. Hayward. 1993. Interpreting hazard rate models Sociological Methods and Research 21:340-371.

Veevers, J.E. and B.A Mitchell, 1994. "Boomerangkids": Perceptions of support when actult children return home. Paper presented at the amual meeting of the Canadian Sociology and Anthropology Association, University of Calgary, May-June.

Veevers, J.E., E.M. Gee, and AV. Wister. 1996. Home-leaving age norms; Conflict or consensus? Intemational Journal of Aging and Human Development; in press.

Ward, R.A and Spitze, G. 1992. Consequences of parent-adult child coresidence. Journal of Family Issues 13:553-572.

White, L K. and A Booth. 1985. The quality and stability of remarriages: The role of stepchildren. American Sociological Review 50:689-698. 
Wister, AV., B.A. Mitchell, and E.M. Gee. 1996. Does money matter?: Parental income and living arrangement satisfaction among "boomerang" children during coresidence. Paper presented at the annual meeting of the Canadian Population Society, Brock University, June.

Wolf, D.A. 1990. Household patterns of older women. Research on Aging 12:463-486.

Yamaguchi, K. 1991. Event history analysis. Applied Social Reseanch Method Series, Vol. 28. Newbury Park: Sage Publications.

\section{Acknowledgements}

This is a revised version of a paper presented at the Warren Kalbach Conference on Current Issues and Research in Population, University of Alberta, March 1995. Research was supported by a grant from the Social Sciences and Humanities Research Council of Canada. The authors thank Doug Talling for his assistance with computer runs, and the anonymous journal reviewers for their helpful comments.

Revised, Aprtl 1995; revised, May 1996.

Appendix A Coding and Frequency Distributions for Independent Variables in the Proportional Hazards Model

\begin{tabular}{llrr} 
Variable & Categories & Frequency & Percent \\
(1) Parental Characteristics & & & \\
Family Type & 1. biological (ref) & 280 & 66.7 \\
& 2. single & 89 & 21.2 \\
& 3. step & 48 & 11.4 \\
& missing & 3 & 0.7 \\
Parental Education & 1. some high school or less & 43 & 10.2 \\
& 2. high school grad or some & 209 & 49.8 \\
Household Income & 3. post-secondary or degree (ref.) & 168 & 40.0 \\
& $1 .<39,999$ & 75 & 17.9 \\
& $2,40,000-79,999$ & 218 & 51.9 \\
(2) Characteristics of Child & 3. 80,000 + (ref.) & 127 & 30.2 \\
Sex & & & \\
& 1. males $=1$ (ref.) & 157 & 37.4 \\
& 2. females $=2$ & 263 & 62.6 \\
\hline
\end{tabular}


Appendix A cont'd.

\begin{tabular}{|c|c|c|c|}
\hline Variable & Categories & Frequency & Percent \\
\hline \multirow[t]{3}{*}{ Religiosity of Child } & 1. neverirarely & 282 & 67.1 \\
\hline & 2. sometimes (ref.) & 96 & 22.9 \\
\hline & 3. once a week & 42 & 10.0 \\
\hline \multirow[t]{5}{*}{ Ethnic Origin of Child } & 1. Commonwealth (ref.) & 273 & 65.0 \\
\hline & Canadian, American, British & & \\
\hline & 2. other European (French & 99 & 23.6 \\
\hline & Canadians included) & 41 & 9.8 \\
\hline & $\begin{array}{l}\text { 3. other } \\
\text { missing }\end{array}$ & 7 & 1.6 \\
\hline \multirow[t]{3}{*}{ Marital Status " } & 1. married/common-law (ref.) & 100 & 23.8 \\
\hline & 2. never married & 302 & 71.9 \\
\hline & 3. ever married & 18 & 4.3 \\
\hline \multirow[t]{3}{*}{ Age of Home-Lenving ${ }^{\circ}$} & 1. $13-18$ & 143 & 34.0 \\
\hline & $2.19-22$ & 212 & 50.5 \\
\hline & $3.23+$ & 65 & 15.5 \\
\hline \multirow[t]{7}{*}{ Primary Reason for Leaving } & 1. form a relationship ${ }^{b}$ & 80 & 19.0 \\
\hline & 2. went to work & 49 & 11.7 \\
\hline & 3. independence (ref) & 152 & 36.2 \\
\hline & 4. conflict at home & 46 & 11.0 \\
\hline & 5. school & 57 & 13.6 \\
\hline & 6. other (e.g., travel) & 35 & 8.3 \\
\hline & missing & 1 & 0.2 \\
\hline \multirow[t]{5}{*}{ Main Activity" } & 1. employed ft/pt (ref.) & 233 & 55.5 \\
\hline & 2. looking for work & 20 & 4.8 \\
\hline & 3. student & 132 & 31.4 \\
\hline & 4. other & 25 & 6.0 \\
\hline & missing & 10 & 2.4 \\
\hline
\end{tabular}

"These variables are time-nested. Family type, marital status and main activity are constructed at the time of first return for returners and at the time of the survey for home-leavers.

bIncludes those leaving to marry or to live with boy/girlfriend.

'Age at home-leaving is used in its interval form for the proportional hazards analysis. Missing values were recoded as the middle-category for ordinal variables and the mode for categorical variables.

ref. $=$ reference category. 